\title{
PENGARUH PROFITABILITAS TERHADAP KEBIJAKAN UTANG MELALUI KEBIJAKAN DEVIDEN (STUDI PADA PERUSAHAAN MANUFAKTUR YANG TERDAFTAR PADA BEI TAHUN 2015-2017)
}

\author{
Muammar Khaddafi, ${ }^{1,}$ Eggy syahputra ${ }^{2}$ \\ ${ }^{1,2}$ Prodi Akuntansi Fakultas Ekonomi dan Bisnis Universitas Malikussaleh Lhokseumawe \\ khaddafi@unimal.ac.id ${ }^{1,}$ eggysyahputra28@gmail.com ${ }^{2}$
}

\begin{abstract}
This study aimed to determine the Effect of Profitability directly or indirectly on Debt Policy through Dividend Policy on Manufacturing Companies listed on the Stock Exchange in 2015-2017. This study used secondary data in the form of financial statements of Manufacturing Companies listed on the Stock Exchange in 2015-2017 which were accessed on ww.idx.com. The study population was 851 manufacturing companies listed on the Indonesia Stock Exchange in 2015-2017. The sample is 38 companies selected using the Purposive sampling method. This quantitative study used path analysis to analyze the data with the help of SPSS 16.0. The results showed that profitability negatively influenced debt policy, dividend policy did not influence debt policy, and profitability negatively influenced the dividend policy of manufacturing companies.
\end{abstract}

Keywords: Debt policy, Profitability, Devidend policy

\section{PENDAHULUAN}

Krisis ekonomi global menjadi kendala bagi perkembangan industri manufaktur di seluruh dunia termasuk Indonesia. Lesunya perekonomian di Amerika Serikat dan Eropa yang merupakan kiblat perekonomian dunia berdampak pada berbagai sektor termasuk sektor manufaktur. Sektor industri manufaktur sangat berperan penting dalam perekonomian nasional. Terbukti dari kontribusi sektor tersebut yang memberikan nilai tambah terbesar diantara sembilan sektor ekonomi lainnya. Berdasarkan angka Produk Domestik Bruto (PDB) menurut harga konstan 2000, pada tahun 2013 kontribusi sektor industri manufaktur terhadap perekonomian mencapai 25,14 persen. Angka ini lebih kecil dibandingkan tahun-tahun sebelumnya. Pada tahun 2010 kontribusi sektor industri manufaktur tanpa migas terhadap perekonomian sebesar 25,33 persen, tahun 2011 sebesar 25,27 persen dan tahun 2012 sebesar 25,17 persen. Dengan kondisi seperti itu tampak bahwa pada tahun 20102013 pertumbuhan industri mengalami penurunan.

Tujuan utama perusahaan adalah untuk meningkatkan kesejahteraan pemegang saham. Kebijakan pendanaan menyangkut aktivitas yang dilakukan untuk memperoleh dana dan menggunakan dana tersebut untuk mencapai tujuan perusahaan. Dana yang dimiliki atau diperoleh perusahaan digunakan sebagai modal untuk menopang kegiatan usahanya. Salah satu kebijakan pendanaan perusahaan adalah penggunaan dana eksternal berupa hutang. Dalam melakukan pembiayaan dengan menggunakan hutang, manajer dituntut untuk membuat keputusan yang tepat. Saat penggunaan hutang semakin meningkat, maka biaya bunga yang harus dibayarkan juga akan meningkat dan dapat mengurangi laba perusahaan. Namun di sisi lain, pembiayaan dengan hutang masih banyak digunakan oleh perusahaan karena dengan adanya modal pinjaman dari luar maka perusahaan mampu menghasilkan keuntungan yang lebih besar.Perusahaan banyak yang mendanai kegiatan dan aktivitasnya dengan menggunakan hutang baik hutangjangka pendek maupun hutang jangka panjang. Semakin besar hutang yang digunakan oleh perusahaan berarti dana yang diperoleh untuk mendanai aktivitasnya menjadi bertambah.

Untuk memenuhi kebutuhan pendanaan, pemegang saham lebih menginginkan pendanaan perusahaan yang dibiayai dengan hutang karena dengan penggunanaan hutang, hak mereka terhadap perusahaan tidak akan berkurang. Tetapi manajer tidak menyukai pendanaan tersebut karena mengandung resiko yang tinggi. Manajer memiliki kepentingan yang berbeda dengan pemegang saham. Pemegang saham berkeinginan pengembalian yang tinggi, sedangkan manajer takut bila memberikan dividen yang tinggi secara berkelanjutan dan harus melakukan kegiatan pendanaan jangka panjang yang akan berdampak kekurangan uang dalam perusahaan untuk kegiatan operasional. Alternatif yang dapat di gunakan oleh pemilik dan manajer untuk pendanaan jangka pajang dapat dilakukan dengan peningkatan hutang.

Kebijakan utang merupakan kebijakan yang sangat penting yang diambil manajer ketika perusahaan akan melakukan ekspansi. Utang memiliki dua keunggulan penting. Pertama, utang dapat menjadi pengurang pajak. Kedua, kreditor akan mendapatkan pengembalian dalam jumlah tetap, sehingga pemegang saham tidak harus membagi keuntungannya jika bisnis berjalan dengan sangat baik. Namun utang juga memiliki kelemahan. Pertama, semakin tinggi rasio utang maka perusahaan tersebut semakin berisiko, sehingga semakin tinggi pula biaya dari utang maupun ekuitasnya. Kedua, jika sebuah perusahaan mengalami masa-masa sulit dan laba operasi tidak 
cukup untuk menutupi beban bunga,para pemegangsahamnya harus menutupi kekurangan tersebut. Jika mereka tidak dapat melakukannya, maka akan terjadi kebangkrutan.

Profitabilitas adalah laba yang diperoleh perusahaan pada periode tertentu. Profitabilitas merefleksikkan earnings untuk pendanaan investasi. Menyarankan manajer untuk menggunakan pecking order untuk keputusan pendanaan. Pecking Order merupakan urutan penggunaan dana untuk investasi yaitu laba ditahan sebagai pilihan pertama, kemudian diikuti oleh hutang dan ekuitas. Pada tingkat profitabilitas rendah, perusahaan menggunakan hutang untuk membiayai operasional. Sebaliknya pada tingkat profitabilitas tinggi perusahaan mengurangi penggunaan hutang. Hal ini disebabkan perusahaan mengalokasikan sebagian besar keuntungan pada laba ditahan sehingga mengandalkan sumber internal dan menggunakan hutang rendah tetapi pada saat mengahadapi profitabilitas rendah perusahaan menggunakan hutang tinggi sebagai mekanisme pentransferan kekayaan kreditur kepada principal.

Kebijakan dividen akan memiliki pengaruh terhadap tingkat penggunaan hutang suatu perusahaan. Menurut Lukman Syamsuddin (2007:10) "kebijakan dividen adalah persentase laba yang dibayarkan kepada pemegang saham dalam bentuk dividen tunai, penjagaan stabilitas dividen dari waktu ke waktu, pembagian dividen saham dan pembelian kembali saham". Pada dasarnya perusahaan juga melakukan kegiatan operasionalnya yang tidak terlepas dari kewajiban untuk membayar dividen guna memberikan balas jasa bagi para pemegang saham. Kebijakan dividen yang stabil menyebabkan adanya keharusan bagi perusahaanuntuk menyediakan sejumlah dana guna membayar jumlah dividen yang tetap tersebut. Adanya kewajiban tersebut, akan membuat manajer semakin hati-hati dan efisien dalam menggunakan hutang.

Hutang dapat sangat membantu dalam mengatasi masalah pendanaan, akan tetapi perlu dipertimbangkan risiko akan terjadinya kebangkrutan pada penggunaan hutang dalam jumlah yang besar. Sebaliknya, pada tingkat penggunaan hutang yang rendah perusahaan mengalokasikan dividen yang tinggi sehingga sebagian besar keuntungan digunakan untuk kesejahteraan pemegang saham.

Berdasarkan latar belakang diatas maka penulis tertarik untuk melakukan penelitian dengan judul "Pengaruh Profitabilitas Terhadap Kebijakan Utang Melalui Kebijakan Deviden (Studi Pada Perusahaan Manufaktur Yang Terdaftar Pada Bei Tahun 2015-2017) “.

\section{TINJAUAN PUSTAKA \\ Teori Sinyal}

Teori sinyal menekankan kepada pentingnya informasi yang dikeluarkan oleh perusahaan terhadap keputusan investasi pihak di luar perusahaan. Informasi merupakan unsur penting bagi investor dan pelaku bisnis karena informasi menyajikan keterangan, catatan untuk keadaan masa lalu, saat ini maupun keadaan yang akan datang bagi kelangsungan hidup perusahaan. Informasi yang lengkap, relevan, akurat dan tepat waktu sangat diperlukan oleh investor di pasar modal sebagai alat analisis untuk mengambil keputusan investasi. Menurut Jogiyanto (2000:392) dalam Anggraini (2012), informasi yang dipublikasikan sebagai pengumuman akan memberikan sinyal bagi investor dalam pengambilan keputusan investasi. Pengumuman informasi tersebut dapat memuat sinyal positif maupun negatif. Jika pengumuman tersebut mengandung nilai positif diharapkan pasar akan bereaksi pada waktu pengumuman diterima. Pada waktu informasi diumumkan dan semua pelaku pasar sudah menerima informasi tersebut, pelaku pasar terlebih dahulu menginterpretasikan dan menganalisis informasi tersebut sebagai sinyal baik atau sinyal buruk. Menurut (Sharpe, 1997:211) dalam Anggraini (2012), pengumuman informasi akuntansi memberikan sinyal bahwa perusahaan mempunyai prospek yang baik di masa yang akan datang sehingga investor tertarik untuk melakukan perdagangan saham. Pasar akan bereaksi yang tercermin melalui perubahan dalam volume perdagangan saham.

\section{Kebijakan Utang \\ Pengertian Utang}

Hutang sering disebut juga sebagai kewajiban, dalam pengertian sederhana dapat diartikan sebagai kewajiban keuangan yang harus dibayaroleh perusahaan kepada pihak lain. Untuk menentukan suatu transaksi sebagai hutang atau bukan sangat tergantung pada kemampuan untuk menafsirkan transaksi atau kejadian yang menimbulkannya.

Menurut Munawir (2004) hutang adalah semua kewajiban keuangan perusahaan kepada pihak lain yang belum terpenuhi, dimana hutang ini merupakan sumber dana atau modal perusahaan yang berasal dari kreditor. Hutang merupakan pengorbanan manfaat ekonomi masa datang yang mungkin timbul karena kewajiban sekarang.Dalam pengambilan keputusan penggunaan hutang perlu dipertimbangkan biaya tetap yang timbul akibat dari hutang tersebut, yaitu berupa bunga hutang yang menyebabkan semakin meningkatnya laverage keuangan.

Tjahjono(2009:152)berpendapatbahwahuta ngadalahkewajibansuatu perusahaan yang timbul dari transaksi pada waktu yang lalu dan harus dibayar dengan kas,barang atau jasa di masa yang akan datang. Sedangkan dalam hal ini Jusup (2005:23) menyatakan bahwa kewajiban merupakanhutang yang harus dibayar oleh perusahaan denganuang atau jasa pada saat tertentu di masa yang akan datang.

\section{Pengertian Kebijakan Utang}

Kebijakan hutang termasuk kebijakan pendanaan perusahaan yang bersumber dari 
eksternal. Penentuan kebijakan hutang ini berkaitan dengan struktur modal karena hutang merupakan salah satu komposisi dalam struktur modal. Perusahaan dinilai berisiko apabila memiliki porsi hutang yang besar dalam struktur modal, namun sebaliknya apabila perusahaan menggunakan hutang yang kecil atau tidak sama sekali maka perusahaan dinilai tidak memanfaatkan tambahan modal eksternal yang dapat meningkatkan operasional perusahaan (Hanafi,2015:318).

Menurut Hanafi (2015:320) terdapat beberapa faktor yang memiliki pengaruh terhadap kebijakan hutang, antara lain :

\section{NDT (Non-Debt Tax Shield)}

Manfaat dari penggunaan hutang adalah bunga hutang yang dapat digunakan untuk mengurangi pajak perusahaan. Namun untuk mengurangi pajak, perusahaandapat menggunakan cara lain seperti depresiasi dan dana pensiun. Dengan demikian, perusahaan dengan NDT tinggi tidak perlu menggunakan hutang yang tinggi.

2. Struktur Aktiva

Besarnya aktiva tetap suatu perusahaan dapat menentukan besarnya penggunaan hutang.Perusahaan yang memiliki aktiva tetap dalam jumlah besar dapat menggunakan hutang dalam jumlah besar karena aktiva tersebut dapat digunakan sebagai jaminan pinjaman.

3. Profitabilitas

Perusahaan dengan tingkat pengembalian yang tinggi atas investasinya akan menggunakan hutang yang relatif kecil. Laba ditahannya yang tinggi sudah memadai membiayai sebagian besar kebutuhan pendanaan.

\section{Risiko Bisnis}

Perusahaan yang memiliki risiko bisnis yang tinggi akan menggunakan hutang yang lebih kecil untuk menghindari risiko kebangkrutan.

5. Ukuran Perusahaan

Perusahaan yang besar cenderung terdiversifikasi sehingga menurunkan risiko kebangkrutan. Disamping itu, perusahaan yang besar lebih mudah dalam mendapatkan pendanaan eksternal

6. Kondisi Internal Perusahaan

Kondisi internal perusahaan menentukan kebijakan hutang dalam suatu perusahaan.

\section{Indikator Kebijakan Utang}

Kebijakan Utang dalam penelitian ini diproksikan dengan Debt toEquity Ratio (DER).Debt to Equity Ratio (DER) merupakan rasio hutang terhadap modal.Rasio ini mengukur seberapa jauh perusahaan dibiayai olehhutang, dimana semakin tinggi nilai rasio ini menggambarkan gejala yangkurang baik bagi perusahaan (Sartono, 2001). Peningkatan hutang padagilirannya akan memengaruhi besar kecilnya laba bersih yang tersedia bagipara pemegang saham termasuk dividen yang diterima karena kewajibanuntuk membayar hutang lebih diutamakan daripada pembagian dividen (Rini,2015).
Kebijakanhutang perusahaan merupakan tindakan manajemen perusahaan dalam mendanai kegiatan operasional perusahaan dengan menggunakan modal yang berasal dari hutang. Dalam penelitian ini kebijakan hutang diukur dengan Debtto Equity Ratio (DER) yang merupakan perbandingan dari total hutang yang dimiliki perusahaan dengan total ekuitasnya.

Untuk menjalankan operasinya setiap perusahaan memiliki berbagai kebutuhan, terutama yang berkaitan dengan dana agar perusahaan dapat berjalan sebagaimana mestinya. Dana selalu dibutuhkan untuk menutupi seluruh atau sebagian dari biaya yang diperlukan. Dana juga dibutuhkan untuk melakukan ekspansi atau perluasan usaha atau investasi baru. Artinya di dalam perusahaan harus selalu tersedia dana dalam jumlah tertentu sehingga tersedia pada saat dibutuhkan.

Dari kedua pendapat ahli diatas dapat disimpulkan bahwa Debt to Equity Ratio merupakan rasio yang digunakan untuk menghitung utang dan modal, yang dapat menutupi utang-utang kepada pihak luar. Debt to equity ratio pada setiap perusahaan tentu berbeda-beda, tergantung karakteristik bisnis dan keberagaman arus kasnya. Perusahaan dengan arus kas yang stabil biasanya memiliki rasio yang lebih tinggi dari rasio kas yang kurangstabil.

Rasio ini menunjukkan hubungan antara jumlah pinjaman jangka panjang yang diberikan kepada para kreditur dengan jumlah modal sendiri yang diberikan oleh pemilik perusahaan. Hal ini biasanya digunakan untuk mengukur financial leverage suatu perusahaan.

Rasio ini dapat dihitung dengan rumus, menurut Harahap (2010: 303)yaitu :

$$
\text { Debt to Equity Ratio }=\frac{\text { Total Hutang }}{\text { Total Ekuitas }}
$$

\section{Profitabilitas \\ Pengertian Profitabilitas}

Sartono (2001:122) menjelaskan bahwa profitabilitas adalah kemampuan perusahaan dalam memperoleh laba dalam hubungannya dengan penjualan, total aktiva, maupun modal sendiri.Return On Asset mengukur evektifitas perusahaan dengan keseluruhan dana yang ditanamkan dalam aktiva yang akan digunakan dalam operasi perusahaan dalam menghasilkan keuntungan (Munawir, 2004:89).

Profitabilitas merupakan kemampuan perusahaan dalam menghasilkan laba. Myers dan Majluf (1984:187) dalam Octavia (2013) berpendapat bahwa manajer keuangan yang menggunakan pecking order theory dengan laba ditahan sebagai pilihan pertama dalam pemenuhan kebutuhan dana dan hutang sebagai pilihan kedua serta penerbitan saham sebagai pilihan ketiga, akan selalu memperbesar profitabilitas untuk meningkatkan laba. 


\section{Tujuan Profitabilitas}

Menurut Kasmir (2011:197), yang menyatakan bahwa :

Tujuan penggunaan rasio profitabilitas bagi peusahaan, maupun bagi pihak luar perusahaan, yaitu:

1. Untuk mengukur atau menghitung laba yang diperoleh perusahaan dalam satu periode tertentu.

2. Untuk menilai posisi laba perusahaan tahun sebelumnya dengan tahun sekarang.

3. Untuk menilai perkembangan laba dari waktu ke waktu.

4. Untuk menilai besarnya laba bersih sesudah pajak dengan modal sendiri.

5. Untuk mengukur produtivitas seluruh dana perusahaan yang digunakan baik modal pinjaman maupun modal sendiri.

\section{Manfaat Profitabilitas}

1. Mengetahui besarnya tingkat laba yang diperoleh perusahaan dalam satu periode.

2. Mengetahui posisi laba perusahaan tahun sebelumnya dengan tahun sekarang.

3. Mengetahui perkembangan laba dari waktu ke waktu.

4. Mengetahui besarnya laba bersih sesudah pajak dengan modal sendiri.

5. Mengetahui produktivitas dari seluruh dana perusahaan yang digunakan baik modal pinjaman maupun modal sendiri.

\section{Jenis - Jenis Rasio Profitabilitas}

Menurut Irham Fahmi (2012:80) ada beberapa jenis rasio profitabilitas diantaranya adalah sebagai berikut:

1. Gross Profit Margin (GPM)

Rasio ini merupakan margin laba kotor, yang memperlihatkan hubungan antara penjualan dan beban pokok penjualan, mengukur kemampuan sebuah perusahaan untuk mengendalikan biaya persediaan.

2. Net Profit Margin (NPM)

Merupakan salah satu rasio yang digunakan untuk mengukur margin laba atas penjualan.Cara pengukuran rasio ini adalah dengan membandingkan laba bersih setelah pajak dengan penjualan bersih.

3. Return On Investment (ROI)

Rasio ini melihat sejauh mana investasi yang telah ditanamkan mampu memberikan pengembalian keuntungan sesuai dengan yang diharapkan. Dan investasi tersebut sebenarnya sama dengan asset perusahaan yang ditanamkan.

4. Return On Equity (ROE)

Rasio ini mengkaji sejauh mana suatu perusahaan mempergunakan sumber daya yang dimiliki untuk mampu memberikan laba atas ekuitas.

\section{Indikator Profitabilitas}

Dalam penelitian ini penulis menggunakan rasio Return On Equity (ROE). Rasio ini menunjukan kemampuan perusahaan untuk menghasilkan laba setelah pajak dengan menggunakan modal sendiri yang dimiliki perusahaan.Rasio ini penting bagi pihak pemegang saham untuk mengetahui efektivitas dan efisiensi pengolahan modal sendiri yang dilakukan oleh pihak manajemen perusahaan.

Return On Equity (ROE) menurut Irham Fahmi (2012:80) adalah: "Return On Equity (ROE) yaitu rasio yang digunakan untuk mengkaji sejauh mana suatu perusahaan mempergunakan sumber daya yang dimiliki untuk memberikan laba atas ekuitas".Sedangkan Return On Equity (ROE) menurut Kasmir (2012:204) adalah: "Return On Equity (ROE) yaitu rasio untuk mengukur laba bersih sesudah pajak dengan modal sendiri secara keseluruhan menunjukan efisiensi penggunaan modal sendiri, semakin tinggi rasio ini semakin baik".

Berdasarkan kedua definisi tersebut di atas dapat disimpulkan bahwa Return On Equity (ROE) adalah rasio untuk mengukur sejauh mana suatu perusahaan untuk mengukur laba bersih sesudah pajak dengan modal sendiri.

Rumus rasio profitabilitas melalui Return On Equity (ROE) atau hasil pengembalian ekuitas,dengan rumus sebagai berikut:

$$
\text { Return On Equity }(\text { ROE })=\frac{\text { Laba bersih }}{\text { Ekuitas }}
$$

(Hanafi \& Halim,2012:82)

Sebelum menilai Return On Equity (ROE), ada baiknya investor mengetahui komponen penting yang terdapat di dalamnya, komponen tersebut adalah:

1. Laba Bersih Setelah Pajak.

2. Total Ekuitas.

Berikut ini penjelasan dari klasifikasi komponen-komponen Return On Equity (ROE) yang telah dipaparkan sebelumnya:

1. Laba Bersih Setelah Pajak

Menurut Sutrisno (2012:20) menyatakan laba bersih setelah pajak adalah laba setelah pajak dikurangi dengan hasil penjualan aktiva tetap, aktiva non tetap, aktiva non produktif, aktiva lain-lain, dan saham penyertaan langsung.

$\mathrm{x} 100 \%$

\section{Total Ekuitas}

Menurut Sutrisno (2012:21) menyatakan total ekuitas adalah seluruh komponen modal dalam neraca perusahaan pada posisi akhir tahun buku dikurangi dengan komponen modal sendiri yang digunakan untuk membiayai aktiva tetap dalam pelaksanaan dan laba tahun berjalan.

Menurut Kasmir (2012:204) rasio ini bisa dikatakan sebagai rasio yang paling penting dalam keuangan perusahaan. Return On Equity (ROE) mengukur pengembalian absolut yang akan diberikan perusahaan kepada para pemegang saham. 
Rasio ini menunjukan efisiensi modal sendiri. Semakin tinggi rasio ini akan semakin baik.

\section{Kebijakan Deviden}

\section{Pengertian Kebijakan Deviden}

Menurut Hendy (2008) dalam Ira (2011), deviden adalah pembagian sebagian laba perusahaan kepada para pemegang saham.Besarnya deviden ini dapat mempengaruhi harga saham.Apabila deviden yang dibayarkan tinggi, maka harga saham cenderung tinggi sehingga nilai perusahaan juga tinggi, sebaliknya, jika deviden yang dibayarkan kecil, maka harga saham perusahaan tersebut juga rendah.Kemampuan membayar deviden erat hubungannya dengan kemampuan perusahaan memperoleh laba.Jika perusahaan memperoleh laba yang besar, maka kemampuan membayar deviden juga besar.

Sartono (2001) menyatakan bahwa kebijakan deviden adalah suatu keputusan apakah laba yang diperoleh perusahaan akan dibagikan kepada pemegang saham, atau akan ditahan guna untuk pendanaan investasi dimasa yang akan datang.

\section{Bentuk-Bentuk Deviden yang Dibagikan}

Dalam pembayaran dividen, perusahaan dapat menggunakan bentuk bentuk tertentu pembayaran dividen. Baridwan (2004) dalam Prapaska (2012) menyatakan dividen yang dibagikan kepada para pemegang saham dapat berbentuk:

1. Dividen yang berbentuk uang

Pembagian dividen yang paling sering dilakukan adalah dalam bentuk uang. Para pemegang saham akan menerima dividen sebesar tarif per lembar dikalikan jumlah lembar yang dimiliki.

2. Dividen yang berbentuk aktiva (selain kas dan saham sendiri)

Dividen yang dibagikan kadang-kadang tidak berbentuk uang tunai, tetapi berupa aktiva seperti saham perusahaan lain atau barang-barang hasil produksi perusahaan yang membagikan dividen tersebut. Pemegang saham yang menerima dividen seperti ini mencatat dalam bukunya dengan jumlah sebesar harga pasar yang diterimanya.

3. Dividen saham (stock dividend)

Penerimaan dividen dalam bentuk saham dari perusahaan yang membagi saham disebut dividen saham. Saham yang diterima berbentuk saham yang sama dengan yang dimiliki atau saham jenis yang lain.

\section{Kebijakan Deviden yang dilakukan Oleh Perusahaan} Kebijakan dividen yang dilakukan perusahaan ada beberapa macammenurut Horne (1986) dalam Jusriani (2013) yaitu;

1. Kebijakan dividen yang stabil. Artinya jumlah dividen per lembar saham(DPS) yang dibayarkan setiap tahunnya relatif tetap selama jangka waktutertentu meskipun laba per lembar saham setiap tahunnya berfluktuasi.

Beberapa alasan yang mendorong perusahaan menjalankan kebijakandividen tersebut antara lain karena :

1) Akanmemberikan kesan kepada para pemodal bahwa perusahaanmempunyai prospek yang baik di masa mendatang dan

2) Adanya golongan pemodal tertentu yang menginginkan kepastiandividen yang akan dibayarkan.

2. Kebijakan dividen tetap dengan penetapan jumlah dividen minimalditambah dividen ekstra. Kebijakan ini menetapkan jumlah rupiahminimal dividen per lembar saham setiap tahunnya, dan jika terjadipeningkatan laba secara drastis atau keadaan keuangan yang lebih baikmaka jumlah tersebut ditambah lagi dengan dividen ekstra.

3. Kebijakan dividen yang konstan. Berarti jumlah dividen per lembarsaham yang dibayarkan setiap tahunnya akan berfluktuasi sesuai denganperkembangan laba bersih yang diperoleh setiap tahunnya. Hal ini berartidividen dianggap mempunyai isi informasi sebagai indikator prospekperusahaan (membaik atau memburuk), maka perubahan kebijakandividen akan meningkatkan atau menurunkan harga saham hanya apabilahal tersebut ditafsirkan sebagai terjadinya perubahan prospekperusahaan.

4. Kebijakan dividen yang fleksibel. Kebijakan dividen yang fleksibelberari besarnya dividen per lembar saham setiap tahunnya disesuaikandengan posisi keuangan dan kebijakan keuangan dari perusahaan yangbersangkutan.

\section{Teori Kebijakan Deviden}

Menurut Baker et al. (2007) dalam Tatang Ary Gumanti (2013:8) ada tujuh teori tentang dividen. Ketujuh teori-teori yang dimaksud sebagai berikut:

1. Teori burung ditangan (bird in the hand theory) menyatakan bahwa investor lebih menyukai dividen tunai daripada dijanjikan adanya imbalan hasil atas investasi (capital gain) dimasa yang akan datang, karena menerima dviden tunai merupakan bentuk dari kepastian yang berarti mengurangi resiko.(Gordon, 1959; 1963; Walter, 1963, Lintner, 1963)

2. Teori sinyal (signaling theory) menyatakan bahwa dividen akan mengurangi ketimpangan informasi (asymmetric of information) antara manejemen dan pemegang saham dengan menyiratkan informasi privat tentang prospek masa 
depan perusahaan. (Bhattaracharya, 1979;1 John dan william 1985).

3. Teori preperensi pajak (tax preference) menyatakan bahwa investor atau pemegang saham lebih menyukai perusahaan yang membagikan dividen sedikit karena jika dividen yang dibayarkan tingi, maka beban pajak yang harus ditanggung oleh investor atau pemegang saham juga akan tinggi. (Elton dan Gruber, 1970; Miller dan Scholes, 1978).

4. Teori efek klien (clientele effect theory) menyatakan bahwa adanya perbedaan dalam besaran dividen yang dibagikan akan membentuk klien yang berbeda-beda juga. (Jensen dan Meckling, 1976; Easterbrook, 1984)

5. Teori keagenan (agency theory) menyatakan bahwa dividen membatu mengurangi biaya keagenan terkait dengan pemisahan kepemilikan dan kendali atas perusahaan. (Jensen dan Meckling, 1976; Easterbrook, 1984)

6. Teori siklus hidup (life cycle theory) menyatakan bahwa dividen cenderung untuk mengkuti pola siklus hidup perusahaan dan dividen yang dibagikan mencerminkan analisis manajemen atas pentingnya ketidak sempurnaan pasar termasuk didalamnya aspek-aspek yang berkaitan dengan pemegang ekuitas (pemilik saham), biaya keagenan, ketimpangan informasi, biaya penerbitan sekuritas (ekuitas), dan biaya-biaya transaksi. Menurut teori ini perusahaan belum banyak membayar dividen, tetapi semakin tua perusahaan dimana danainternal perusahaan sudah melebihi peluang investasi dividen yang dibayarkan akan meningkat. (Fama dan French,2001; DeAngelo, 2006)

7. Teori katering (catering theory) menyatakan bahwa manajer memberikan investor apa yang sebenarnya diinginkan oleh investor, yaitu manajer menyenangkan investor dengan membayar dividen manakala investor berani memberi premi harga saham yang tinggi tetapi manajer tidak akan membagi dividen manakala investor lebih menyukai perusahaan yang tidak membayar dividen (Baker dan Wurgler, 2004a,b)

\section{Aspek-Aspek Kebijakan Dividen}

Menurut I Made Sudana (2011:171) ada beberapa aspek kebijakan dividen antara lain:

1. Stabilitas dividen

Perusahaan yang membayar dividen secara stabil dari waktu ke waktu kemungkinan dinilai lebih baik daripada perusahaan yang membayar dividen secara berfluktuasi.Hal ini karena perusahaan yang membayar dividen secara stabil mencerminkan kondisi keuangan perusahaan tersebut stabil dan sebaliknya, perusahaan dengan dividen tidak stabil mencerminkan kondisi keuangan perusahaan yang kurang baik.

2. Target payout ratio

Sejumlah perusahaan mengikuti kebijakan target dividend payout ratio jangka panjang. Hal ini akan mengakibatkan besarnya jumlah dividen yang dibayarkan berfluktuasi atau dividennya tidak stabil. Perusahaan hanya akan meningkatkan dividend payout ratio, jika pendapatan perusahaan meningkat dan perusahaan merasa mampu mempertahakan kenaikan pendapatan tersebut dalam jangka panjang.

3. Dividen reguler dan dividen ekstra

Salah satu cara perusahaan meningkatkan dividen kas adalah dengan memberikan dividen ekstra di samping dividend reguler. Hal ini biasanya dilakukan jika pendapatan perusahaan meningkat cukup besar, tetapi sifatnya sementara.Apabila tidak terjadi peningkatan pendapatan perusahaan, dividen yang dibagikan hanya dividend reguler.

\section{Indikator Kebijakan Deviden}

Mengukur dividen yang dibayarakan oleh perusahan dapat diukur menggunakan salah satu dari ukuran umum dikenal. Menurut Tatang Ary Gumanti (2013:22) ukuran kebijakan dividen sebagai berikut:

1. Dividend yield, yang mengaitkan besaran dividen dengan harga saham perusahaan. Secara matematis, rumusan dividend yield adalah sebagai berikut:

Deviden yield

$$
=\frac{\text { Deviden Tahunan Per saham }}{\text { Harga Per Lembar Saham }}
$$

2. Dividend payout, rasio pembayaran dividen diukur dengan cara membagi besarnya dividen per lembar saham dengan laba bersih per lembar saham, yang secara matematis dapat dinyatakan dengan rumus berikut:

Devidend Payout Ratio (DPR) $=\frac{\text { Deviden Tunai Per Lembar Saham }}{\text { Laba bersih Per Lembar Saham }}$

Kebijakan dividen dalam penelitian ini diukur menggunakan DividendPayout Ratio (DPR).Dividend payout ratio adalah presentase pembagiandividen dari laba bersih. Dividend payout ratio dihitung dengan caramembandingkan antara dividen yang dibagi dengan laba bersih yangdidapatkan dan biasanya disajikan dalam bentuk persentase. Semakin tinggidividend payout ratio akan menguntungkan para investor tetapi dari pihakperusahaan akan memperlemah internal financing karena memperkecil labaditahan. Tetapi sebaliknya dividend payout ratio semakin kecil akanmerugikan investor (para pemegang saham) tetapi internal financingperusahaan akan semakin kuat.

Kerangka Konseptual

Hubungan Profitabilitas terhadap Kebijakan Utang 
Profitabilitas merefleksikan pendapatan untuk pendanaan investasi. menyarankan manajer untuk menggunakan pecking order untuk keputusan pendanaan. Pecking Order merupakan urutan penggunaan dana untuk investasi yaitu laba ditahan sebagai pilihan pertama, kemudian diikuti oleh hutang dan ekuitas. Jika ini benar, implikasinya adalah ada hubungan negatif antaraprofitabilitas perusahaan dengan debt ratio. Pihak insider tidak mau berbagi keuntungan dengan kreditur sehingga ada kecenderungan debt ratio perusahaan lebih kecil. Nurbaiti (2007) menemukan adanya pengaruh negatif dan signifikan antara profitabilitas terhadap kebijakan hutang. Hasil ini senada dengan penelitian yang dilakukan oleh Ismayanti dan Hanafi (2003). Pada tingkat profitabilitas rendah, perusahaan menggunakan hutang untuk membiayai operasional. Sebaliknya pada tingkat profitabilitas tinggi perusahaan mengurangi penggunaan hutang.

Hal ini disebabkan perusahaan mengalokasikan sebagian besar keuntungan pada laba ditahan sehingga mengandalkan sumber internal dan menggunakanhutang rendah tetapi pada saat menghadapi profitabilitas rendah perusahaan menggunakan hutang tinggi sebagai mekanisme pentransfer kekayaan kreditur kepada principal. Berbeda dengan hasil penelitian tersebut, Masdupi (2005) menemukan hasil yang tidak signifikan secara statistik antara prifitabilitas terhadap kebijakan hutang.

\section{Hubungan Kebijakan Deviden terhadap} Kebijakan Utang

Kebijakan dividen akan memiliki pengaruh terhadap tingkat penggunaanhutang suatu perusahaan. Kebijakan dividen yang stabil menyebabkan adanya keharusan bagi perusahaan untuk menyediakan sejumlah dana guna membayar jumlah dividen yang tetap tersebut. Menurut Faisal (2002) dalam Murni dan Andriana (2007) perusahaan yang mempunyai dividen tinggi akan menyukai perusahaan dengan modal sendiri. Disamping itu, pembayaran dividen dapat dilakukan setelah kewajiban pembayaran bunga dan cicilan hutang dipenuhi. Adanya kewajiban tersebut, akan membuat manajer semakin hati-hati dan efisien dalam menggunakan hutang. Hasil peneilitan Murni dan Andriana (2007)menghasilkan pengaruh yang signifikan dan negatif antara pembayar dividen terhadap kebijakan hutang.

Perusahaan akan mengurangi pembayaran dividen karena sebagian besar keuntungan di gunakan untuk membayar bunga dan cicilan pinjaman. Sedangkan pada penelitian Faisal (2000) dalam Murni dan Andriana (2007), dan Wahidahwati (2002) tidak menghasilkan pengaruh yang signifikan walaupun arah yang dihasilkan juga negatif.

\section{Hubungan Profitabilitas terhadap Kebijakan Deviden \\ Profitabilitas merupakan variabel yang menunjukkan kemampuan perushaan dalam menghasilkan keuntungan. Berdasarkan hasil penelitian}

Sulistyowati et al (2010), Anil dan Kapoor (2008),Kadir (2010), dan Deitiana (2009), profitabilitas berpengaruh positif terhadap kebijakan dividen dikarenakan profitabilitas merupakan kemampuan perusahaan untuk menghasilkan laba dan dividen akan dibagi apabila perusahaan tersebut memperoleh laba. Menurut Wirjolukito dalam Suharli (2007) dalam Sulistyowati (2010), profitabilitas mutlak diperlukan untuk perusahaan apabila hendak membayar dividen. Laba setelah pajak yang diperoleh perusahaan sebagian dibagikan dalam bentuk dividen dan sebagian lain ditahan di perusahaan (laba ditahan). Jika laba yang diperoleh kecil, maka dividen yang akan dibagikan juga kecil. Sedangkan jika laba yang diperoleh besar, maka dividen yang akanditerima pemegang saham juga akan besar (Darminto, 2008).

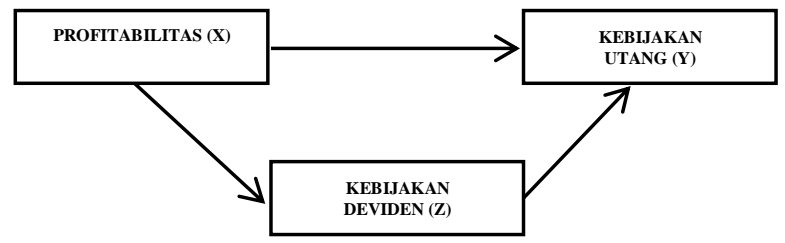

\section{Gambar 1 Kerangka Konseptual}

\section{Hipotesis Penelitian}

Berdasarkan kerangka konseptual diatas maka diperoleh rumusan hipotesis sebagai berikut :

H1: Profitabilitas berpengaruh terhadap Kebijakan Utang

H2: Kebijakan Deviden berpengaruh terhadap Kebijakan Utang

H3: Profitabilitas berpengaruh terhadap Kebijakan Deviden

\section{METODE PENELITIAN \\ Lokasi dan Objek Penelitian}

Penelitian ini mengambil lokasi pada perusahaan manufaktur yang tedaftar di Bursa Efek Indonesia. Yang menjadi objek penelitian adalah data mengenai kebijakan utang dan kebijakan deviden serta profitabilitas perusahaan manufaktur yang terdaftar di BursaEfek Indonesia (periode 2015-2017). melalui website $w w w . i d x . c o . i d$ dan www.yahoofinance.com

\section{Populasi dan Sampel Populasi}

Populasi adalah sekumpulan objek yang lengkap yang terdiri atas orang, kejadian, atau benda yang memiliki karakteristik yang umum dalam penelitian. Menurut Sugiono (2014), populasi merupakan wilayah generalisasi yang terdiri atas objek atau subjek yang mempunyai kualitas dan karakteristik tertentu yang ditetapkan oleh peneliti untuk dipelajari dan kemudian ditarik kesimpulannya. 
Populasi dalam penelitian ini adalah seluruh Bank Umum Syariah yang terdaftar di Bursa Efek Indonesia (BEI) periode tahun 2013 sampai dengan 2018 yang berjumlah 12 perbankan.

\section{Populasi dan Sampel \\ Populasi Penelitian}

Sugiyono (2009:80) menyatakan bahwa populasi adalah wilayah generalisasi yang terdiri atas: objek/subjek yang mempunyai kualitas dan karakteristik tertentu yang ditetapkan oleh peneliti untuk dipelajari dan kemudian ditarik kesimpulan. Adapun yang menjadi populasi dalam penelitian ini adalah seluruh perusahaanmanufaktur di bursa efek Indonesia periode 2015-2017 yaitu sebanyak 851 perusahaan.

\section{Kriteria Pengambilan Sampel}

Berdasarkan kriteria diatas, maka sampel dalam penelitian ini adalah sebanyak 38 perusahaanmanufaktur yang terdaftar di bursa efek Indonesia tahun

2015-2017sehingga total observasimenjadi114 (38perusahaanselama 3 tahun).

\section{JenisdanSumbe rData}

Jenis data yang diambil peneliti dalam penelitian ini berdasarkan dengan kelompok jenis data yaitu: Jika dilihat berdasarkan cara perolehan data ini merupakan data sekunder dikarenakan penelitian ini menggunakan data dari laporan keuangan dari perusahaan yang bersangkutan. Jenis data dalam penelitian ini merupakan data runtun waktu (time series), data mengenai profitabilitas, kebijakan deviden dan kebijakan utang di ambil dari periode 2015-2017. Jika dilihat berdasarkan sifatnya ini merupakan data kuantitatif dikarenakan data ini menguji kembali dari teori-teori yang sudah ada dan data yang dianalisis berupa data keuangan yang bersifat kuantitatif.

\section{Metode Pengumpulan Data}

Teknik pengumpulan data merupakan langkah yang paling utama dalam penelitian, karena tujuan utama dari penelitian adalah mendapatkan data. Tanpa mengetahui teknik pengumpulan data, maka peneliti tidak akan mendapatkan data yang memenuhi standar yang ditetapkan (Sugiyono, 2013:224).

Dalam penelitian ini, peneliti mengumpulkan data dengan studi pustaka dan dokumentasi. Studi pustaka digunakan untuk melihat literatur-literatur mengenai informasi gambaran umum tentang objek penelitian sedangkan teknik dokumentasi digunakan untuk mendokumentasikan laporan-laporan keuangan Perusahaan manufaktur yang terdaftar di BEI pada tahun 2015 sampai dengan 2017.

\section{Operasional Variabel \\ Variabel Dependen (Y) Kebijakan Utang}

Variabel dependen dalam penelitian ini adalah Kebijakan Utang. Kebijakan Utang atau yang bisa disebut dengan DER (Devident to Equity Ratio) dapat di ukur dengan membagi total utang dengan total ekuitas (Maharani,Dkk).

\section{Variabel Independen (X) \\ Profitabilitas}

Dalam Penelitian ini Variabel Independen yang digunakan adalah profitabilitas. Profitabilitas merupakan kemampuan perusahaan dalam memperoleh laba.

\section{Variabel Intervening $(\mathbf{Z})$ \\ Kebijakan Deviden}

Dalam penelitian ini dijelaskan Variabel Intervening adalah kebijakan deviden. Kebijakan Deviden merupakan suatu keputusan pada perusahaan apakah laba perusahaan tersebut dibagikan ke pemegang saham atau ditahan guna untuk pendanaan investasi di masa yang akan datang.

\section{Metode Analisis \\ Metode analisis yang digunakan dalam penelitian ini adalah dengan melakukan analisis kuantitatif yang dinyatakan dengan angka-angka yang dalam perhitungannya menggunakan metode statistik yang dibantu dengan program pengolah data statistik yang dikenal dengan SPSS versi 24 . Metode-metode yang digunakan yaitu analisis deskriptif, uji asumsi klasik, uji analisis jalur (Path analysis) dan uji hipotesis}

\section{Analisis Deskriptif}

Statistik deskriptif adalah statistik yang digunakan untuk menganalisis data dengan cara mendeskripsikan atau menggambarkan data yang telah terkumpul sebagaimana mestinya (Sugiyono, 2013:206). Analisis deskriptif ini digunakan untuk memberikan gambaran atau deskripsi mengenai variabel dependen yaitu kebijakan utang serta variabel independen yaitu profitabilitas dan variabel moderating berupa kebijakan hutang.

Analisis ini disajikan dengan menggunakan tabel statistic descriptive yang memaparkan nilai maksimum, minimum, rata-rata (mean) dan standar deviasi. Maksimum dan minimum digunakan untuk melihat nilai maksimum dan minimum dari sampel. Rata-rata (mean) digunakan untuk memperkirakan rata-rata populasi yang diperkirakan dari sampel. Hal ini diperlukan untuk melihat gambaran keseluruhan dari sampel yang berhasil dikumpulkan berdasarkan kriteria.

\section{Uji Asumsi Klasik}

Menurut ikhsan, dkk (2014:185-186) uji asumsi klasik dilakukan untuk mengetahui apakah model estimasi telah memenuhi kriteria ekonometrika, dalam arti tidak terjadi penyimpangan yang cukup serius dari asumsi-asumsi yang harus dipenuhi dalam metode Ordinary Least Square $(O L S)$. 
Sedikitnya terdapat empat uji asumsi yang harus dilakukan terhadap suatu model regresi sederhana, yaitu:

1. Uji Normalitas

2. Uji Autokorelasi

3. Uji Heteroskedasitas

\section{Uji Normalitas}

Menurut Imam Ghozali (2013:160) uji normalitas bertujuan untuk menguji apakah dalam model regresi, variabel pengganggu atau residual memiliki distribusi normal.Seperti diketahui bahwa uji $\mathrm{t}$ dan $\mathrm{F}$ mengasumsikan bahwa nilai residual mengikuti distribusi normal.

Penelitian ini mengunakan pendekatan grafik Normal P-P of regression standardized residual untuk menguji normalitas data dan pendekatan uji statistik Kormogolov-Smirnov. Untuk pendekatan grafik jika data menyebar disekitar garis diagonal atau grafik histogramnya menunjukan pola distribusi norma ,maka model regresi memenuhi asumsi normalitas. Jika data menyebar jauh dari diagonal atau tidak mengikuti arah garis diagonal atau grafik histogram tidak menunjukan pola distribusi normal,maka model regresi tidak memenuhi asumsi normalitas (Imam Ghozali,2013:163).

\section{Uji Autokorelasi}

Uji autokorelasi bertujuan menguji apakah dalam model regresi linear ada korelasi antara kesalahan pengganggu pada periode $t$ dengan kesalahan pengganggu pada periode $\mathrm{t}-1$ (sebelumnya) (Imam Ghozali,2013:110). Autokorelasi muncul karena observasi yang berurutan sepanjang waktu berkaitan satu sama lainnya. Hal ini sering ditemukan pada data runtut waktu (time series) karena "gangguan" pada seseorang individu atau kelompok cenderung mempengaruhi "gangguan" pada individu atau kelompok yang sama pada periode berikutnya. Dalam penelitian ini,peneliti menggunakan pendekatan Durbin- Waston (DW test), dikarenakan sampel yang digunakan dibawah 100. Sedangkan jika sampel diatas 100 maka harus menggunakan pendekatan Lagrange Multiplier (LM test). Uji Durbin-Woston hanya digunakan untuk autokorelasi tingkat satu dan mensyaratkan adanya konstanta dalam model regresi dan tidak ada variabel lag diantara variabel independen(Imam Ghozali, 2013:111).

Pendekatan yang sering digunakan untuk menguji ada tidaknya autokorelasi adalah uji Durbin-Watson (DW test) (Imam Ghozali, 2013:110) :

\section{Uji Heteroskedastisitas}

Uji heteroskedastisitas bertujuan untuk menguji apakah dalam model regresi terjadi ketidaksamaan variansi dari residual satu pengamatan ke pengamatan lain (Imam
Ghozali,2013:139). Pengujian heteroskedastisitas dilakukan dengan menggunakan uji Glejser (Gujarati,2003) yang dikutip oleh Imam Ghozali (2013:142). Pada uji Glejser, nilai residual absolut diregresi dengan variabel independen. Jika variabel independen signifikan secara statistik mempengaruhi variabel dependen,maka terdapat indikasi terjadi Heteroskedasitas.

\section{Uji Hipotesis}

Uji t dimaksudkan untuk menguji apakah secara individual ada pengaruh antara variabelvariabel bebas dengan variabel terikat.Penguji secara parsial untuk setiap koefisien regresi diuji untuk mengetahui pengaruh secara parsial antara variabel bebas dengan variabel terikat pada tingkat signifikan yang dipilih (Arfan Ikhsan 2014).

Pengujian hipotesis terhadap koefisien regresi secara parsial menggunakan uji t terhadap tingkat keyakinan $95 \%$ dan tingkat keahlian $5 \%$ dengan ketentuan degree of fredom $(\mathrm{df})=\mathrm{n}-\mathrm{k}$, dimana $\mathrm{n}=$ besar sampel, $\mathrm{k}=$ jumlah variabel. Jika $\mathrm{p}$ - value $<\alpha($ Sig. $5 \%) \mathrm{H}_{1}$ diterima, artinya variabel independen secara parsial tidak mempunyai pengaruh yang signifkan terhadap pendapatan dependen. Selain, itu, dapat juga melihat probabilitas, jika nilai probabilitas lebik kecil dari pada 0,05 (untuk tingkat signifikan $=5 \%$ ), maka varibel independen secara satu persatu berpengaruh terhadap variabel dependen.dan sebaliknya, jika p value nilai (sig. $5 \%$ ) $\mathrm{H}_{1}$ ditolak, Ha diterima artinya variabel independen secara parsial tidak mempunyai pengaruh yang signifikan terhadap variabel dependen, jika melihat probabilitas, maka nilai probabilitas lebih besar dari 0,05 (untuk tingkat signifikan 5\%), maka tidak terdapat pengaruh secara parsial variabel independen terhadap dependen Arfan Ikhsan at,al (2014).

Pengujian hipotesis dalam penelitian ini untuk menguji seluruh variabel bebas terhadap variabel terikat melalui variabel intervening. Dengan ketentuan uji sebagai berikut :

1. Jika $\mathrm{p}-$ value $<\alpha($ sig. $5 \%) \mathrm{H}_{1}$ diterima

2. Jika $\mathrm{p}-$ value $>\alpha($ sig. $5 \%) \mathrm{H}_{1}$ ditolak

\section{Koefisien Determinasi (R2)}

Koefisien determinasi pada intinya digunakan untuk mengukur seberapa jauh kemampuan model dalam menerangkan variasi variabel independen (Ghozali, 2009).Nilai koefisien determinasi berkisar antara nol sampai dengan satu.Nilai R2 yang kecil menunjukkan kemampuan variabel-variabel independen dalam menjelaskan variabel dependen amat terbatas.Sebaliknya, nilai R2 yang mendekati satu menunjukkan variabel-variabel independen memberikan hampir semua informasi yang dibutuhkan untuk memprediksi variabel dependen. Kelemahan mendasar pada penggunaan koefisien determinasi adalah bias terhadap jumlah variabel independen yang 
dimasukkan ke dalam model. Setiap tambahan satu variabel independen, maka R2 pasti akan meningkat tanpa melihat apakah variabel tersebut berpengaruh secara signifikan terhadap variabel dependen. Oleh karena itu, banyak peneliti menganjurkan untuk menggunakan adjusted R2 untuk mengevaluasi model regresi karena adjusted R2 dapat naik atau turun apabila satu variabel independen ditambahkan ke dalam model (Ghozali, 2009).

\section{Uji Analisis jalur (Path Analysis)}

Analisis jalur merupakan perluasan dari analisis regresi linear berganda atau analisis jalur adalah penggunaan analisis jalur regresi untuk menaksir hubungan kausalitas antar variabel yang ditetapkan sebelumnya berdasarkan teori (Pratama, 2015). Untuk menguji pengaruh variabel intervening, metode analisis jalur (path analysis). Berdasarkan penlitian ini maka model analisis jalur dapat digambarkan sebagai berikut:

Pengaruh Langsung :

- $\mathrm{X}$ terhadap $\mathrm{Y}$ dengan Persamaan $\mathrm{Y}=$ $\mathrm{p}_{1} \mathrm{x}_{1 \mathrm{y}} \mathrm{X}+\mathrm{e}$

- $\quad Z$ terhadap $Y$ dengan Persamaan $Y=p_{2} x_{1 y}$ $\mathrm{Z}+\mathrm{e}$

Pengaruh tidak Langsung :

$\mathrm{X}$ terhadap $\mathrm{Y}$ dengan persamaan $\mathrm{Y}=$ $\left(\mathrm{p}_{1} \mathrm{x}_{1 \mathrm{y}}\right)\left(\mathrm{p}_{2} \mathrm{x}_{1 \mathrm{zy}}\right) \mathrm{X}+\mathrm{e}$

\section{HASIL DAN PEMBAHASAN}

\section{Uji Analisis Deskriptif}

Tabel analisis deskriptif menunjukkan variabel yang digunakan dalam penelitian ini, yaitu Variabel Y (Kebijakan Utang) sebagai variabel dependen. Variabel $\mathrm{X}_{1}$ (Profitabilitas) sebagai variabel independen. Penjelasan dari masing-masing variabel pada tabel 4.1 berikut ini:

\section{Tabel 1}

Analisis Deskriptif

\begin{tabular}{|c|c|c|c|}
\hline & Mean & $\begin{array}{c}\text { Std. } \\
\text { Deviation }\end{array}$ & $\mathrm{N}$ \\
\hline Kebijakan Utang &, 3085184 &, 17672792 & 114 \\
Profitabilitas &, 5798504 &, 55468897 & 114 \\
\hline
\end{tabular}

Data diolah: Hasil penelitian SPSS (2019)

Variabel profitabilitas selama periode pengamatan (2015-2017) memilikinilai rata-rata (mean) sebesar 0,5798 dengan nilai standar deviasi sebesar 0,5546 yangmenunjukkan bahwa nilai standar deviasi lebih rendah dibandingkan nilai ratarata(mean). Hal ini mengindikasikan bahwa data variabel profitabilitas selama periodepengamatan dapat dikatakan baik.Variabel kebijakan utang selama periode pengamatan (2015-2017)memiliki nilai rata-rata (mean) sebesar 0,3085 dengan nilai standar deviasi sebesar 0,1767 yang menunjukkan bahwa nilai standar deviasi lebih rendah dibandingkannilai rata-rata (mean). Hal ini mengindikasikan bahwa data variabel kebijakan utang selamaperiode pengamatan dapat dikatakan baik.

\section{Uji Asumsi Klasik}

Model regresi yang yang baik harus bebas dari masalah asumsi klasik. Uraian berikut akan membahas mengenai uji asumsi klasikdiantaranya:

\section{Uji Normalitas}

Uji normalitas bertujuan untuk menguji apakah dalam suatu model regresi linear berganda variabel bebas dan variabel terikat keduanya mempunyai distribusi normal atau tidak.Model regresi yang baik adalah memiliki distribusi data normal atau mendekati normal.Uji normalitas dapat diketahui dengan melihat normal probability plot. Distribusi normal akan membentuk satu garis lurus diagonal dan ploting data residual akan dibandingkan dengan garis diagonal. Jika distribusi data residual normal, maka titik-titik yang menggambarkan data akan mengikuti garis diagonalnya.

\section{Uji Normalitas Variabel Profitabilitas Terhadap Kebijakan Utang}

Kurva normal p-p plot untuk pengujian normalitas regresi linearantara Profitabilitas terhadap Kebijakan Utang dapat dilihat hasilnya sebagai berikut:

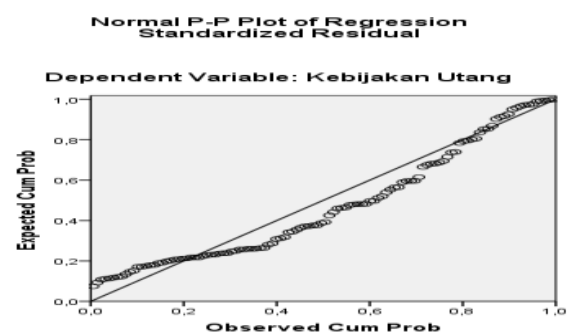

Gambar 4.1

\section{Uji Hipotesis}

$$
\text { Pengujian hipotesis merupakan }
$$

pembuktian statistik atas semua yang telah dihipotesiskan dalam penelitian berdasarkan teori. Untuk menguji hipotesis yang telah diajukan dan untuk mendeteksi pengaruh variabel mediasi (variabel intervening) dalam memediasi variabel independen terhadap variabel dependen digunakan metode Analisis Regresi dan AnalisisJalur.

Analisis Jalur merupakan perluasan dari analisis regresi, atau dengan kata lain analisis jalur adalah penggunaan analisis regresi untuk menaksir hubungan kausalitas antar variabel yang telah ditetapkan sebelumnya berdasarkan teori.

\section{Pengujian Hipotesis 1}

1. Analisis regresi profitabiltas terhadap kebijakan utang. 
Berdasarkan dari hasil analisis dengan menggunakan program SPSS maka diperoleh hasil regresi profitabilitas terhadap kebijakan utang sebagai berikut :

Tabel 3

Coefficients $^{\mathrm{a}}$

\begin{tabular}{|l|l|l|l|}
\hline \multirow{2}{*}{ Model } & \multicolumn{2}{|l|}{$\begin{array}{l}\text { Unstandardi } \\
\text { zed } \\
\text { Coefficients }\end{array}$} & $\begin{array}{l}\text { Standardi } \\
\text { zed } \\
\text { Coefficie } \\
\text { nts }\end{array}$ \\
\cline { 2 - 4 } & B & $\begin{array}{l}\text { Std. } \\
\text { Error }\end{array}$ & Beta \\
\hline (Constant) &, 347 &, 024 & \\
Profitabilitas &,- 066 &, 029 &,- 208 \\
& & & \\
\hline
\end{tabular}

Data diolah: Hasil Penelitian SPSS (2019)

Dari hasil regresi yang didapat maka dapat dibuat persamaaan regresi sebagai berikut : $\mathrm{Y} 1=-0,208 \mathrm{X}_{1}+\mathrm{e}$

Persamaan regresi tersebut mempunyai arti sebagai berikut, koefisien regresi kompensasi (b1) bernilai negatifsebesar -0,208 dengan signifikansi sebesar 0,026. Nilai signifikansi profitabilitas $(0,026)$ yang lebih kecil dari nilai signikansi yang di harapkan $(0,05)$ menunjukkan bahwa variabel profitabilitas berpengaruh terhadap kebijakan utang.

2. Koefesien determinasi profitabilitas terhadap kebijakan utang.

Hasil koefesien determinasi antara profitabilitas terhadap kebijakan utangdapat dilihat hasilnya pada tabel berikut :

Tabel 4

Model Summary ${ }^{\text {b }}$

\begin{tabular}{|c|c|c|c|c|}
\hline $\begin{array}{l}\text { Mod } \\
\text { el }\end{array}$ & $\mathrm{R}$ & $\begin{array}{l}\mathrm{R} \\
\text { Squar } \\
\mathrm{e}\end{array}$ & $\mid \begin{array}{ll}\text { Adjusted } & \mathrm{R} \\
\text { Square } & \end{array}$ & $\begin{array}{l}\text { Std. Error of the } \\
\text { Estimate }\end{array}$ \\
\hline 1 & $.208^{\mathrm{a}}$ & .043 & .035 & .17361812 \\
\hline
\end{tabular}

a. Predictors: (Constant), Profitabilitas

b. Dependent Variable: Kebijakan Utang

Data diolah: Hasil Penelitian SPSS (2019)

Berdasarkan tabel 4.4 tampilan output SPSS model summary, besarmya NilaiAdjusted $R$ Square adalah 0,035. Hal ini menunjukkan bahwa profitabilitas mampu mempengaruhi kebijakan utang sebesar 3,5\%sedangkan sisanya dijelaskan oleh faktor faktor lain yang tidak diteliti dalam penelitian ini.

\section{Pengujian Hipotesis 2}

1. Analisis regresi kebijakan deviden terhadap kebijakan utang,

Berdasarkan dari hasil analisis dengan menggunakan program SPSS maka diperoleh hasil regresi kebijakan deviden terhadap kebijakan utang sebagai

berikut :

Tabel 5

Coefficients $^{\mathrm{a}}$

\begin{tabular}{|c|c|c|c|c|c|}
\hline \multirow[b]{2}{*}{ Model } & \multicolumn{2}{|c|}{$\begin{array}{l}\text { Unstandardized } \\
\text { Coefficients }\end{array}$} & \multirow{2}{*}{ 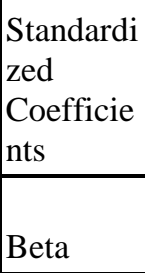 } & \multirow[b]{2}{*}{$\mathrm{T}$} & \multirow[b]{2}{*}{ Sig. } \\
\hline & B & $\begin{array}{l}\text { Std. } \\
\text { Error }\end{array}$ & & & \\
\hline 1 (Constant) & .278 & .032 & & \begin{tabular}{|l|}
8.79 \\
0
\end{tabular} & .000 \\
\hline $\begin{array}{l}\text { Kebijakan } \\
\text { Devident }\end{array}$ & .073 & .064 & .106 & $\begin{array}{l}1.12 \\
9\end{array}$ & .261 \\
\hline
\end{tabular}

a. Dependent Variable: Kebijakan Utang

Data diolah: Hasil Penelitian SPSS (2019)

Dari hasil regresi yang didapat maka dapat dibuat persamaaan regresi sebagai berikut : $\mathrm{Z} 1=0,106 \mathrm{Y}+\mathrm{e}$

Persamaan regresi tersebut mempunyai arti sebagai berikut, Koefisien regresi kompensasi (b1) bernilai positif sebesar 0,106 dengan signifikansi sebesar 0,261. Nilai signifikansi kebijakan deviden $(0,261)$ yang lebih besar dari nilai signikansi yang di harapkan $(0,05)$ menunjukkan bahwa variabel kebijakan deviden tidak berpengaruh terhadap kebijakan utang.

1. Koefesien determinasi kebijakan deviden terhadap kebijakan utang

Hasil koefesien determinasi kebijakan devidenterhadap kebijakan utang dapat dilihat hasilnya pada tabel berikut :

Tabel 6

Model Summary ${ }^{b}$

\begin{tabular}{|l|l|l|l|l|}
\hline & & & & \\
Model & $\mathrm{R}$ & R Square & $\begin{array}{l}\text { Adjusted R } \\
\text { Square }\end{array}$ & $\begin{array}{l}\text { Std. Error of the } \\
\text { Estimate }\end{array}$ \\
\hline 1 & $.106^{\mathrm{a}}$ & .011 & .002 & .17651402 \\
\hline
\end{tabular}

a. Predictors: (Constant), Kebijakan Devident

b. Dependent Variable: Kebijakan Utang

Data diolah: Hasil Penelitian SPSS (2019) 
Berdasarkan tabel 4.6 tampilan output SPSS model summary, besarmya Nilai Adjusted $R$ Square adalah 0,002. Hal ini menunjukkan bahwa profitabilitas mampu mempengaruhi kebijakan utang sebesar 2\% sedangkan sisanya dijelaskan oleh faktor faktor lain yang tidak diteliti dalam penelitian ini.

\section{Pengujian Hipotesis 3}

1. Analisis regresi profitabiltas terhadap kebijakan deviden

Berdasarkan dari hasil analisis dengan menggunakan program SPSS maka diperoleh hasil regresi antara profitabilitas terhadap kebijakan deviden melalui Kebijakan Deviden sebagai berikut

Tabel 7

Coefficients $^{\mathrm{a}}$

\begin{tabular}{|c|c|c|c|c|c|}
\hline \multirow[b]{2}{*}{ Model } & \multicolumn{2}{|c|}{$\begin{array}{l}\text { Unstandardized } \\
\text { Coefficients }\end{array}$} & \multirow{2}{*}{\begin{tabular}{|l} 
Standardi \\
zed \\
Coefficie \\
nts
\end{tabular}} & \multirow[b]{2}{*}{$\mathrm{T}$} & \multirow[b]{2}{*}{ Sig. } \\
\hline & B & $\begin{array}{l}\text { Std. } \\
\text { Error }\end{array}$ & & & \\
\hline 1(Constant & .477 & .034 & & 13.850 & .000 \\
\hline $\begin{array}{l}\text { Profitabili } \\
\text { tas }\end{array}$ & -.099 & .043 & -.212 & -2.298 & .023 \\
\hline
\end{tabular}

a. Dependent Variable: Kebijakan Devident

Data diolah: Hasil Penelitian SPSS (2019)

Dari hasil regresi yang didapat maka dapat dibuat persamaaan regresi sebagai berikut : $\mathrm{Y}=-0,212 \mathrm{Z}+\mathrm{e}$

Persamaan regresi tersebut mempunyai arti sebagai berikut, Koefisien regresi kompensasi (b1) bernilai negatif sebesar -0,212 dengan signifikansi sebesar 0,023 . Nilai signifikansi kebijakan deviden $(0,023)$ yang lebih kecil dari nilai signikansi yang di harapkan $(0,05)$ menunjukkan bahwa variabel profitabilitas berpengaruh terhadap kebijakan deviden.
2. Koefisien Determinasi Profitabiltas Terhadap Kebijakan Deviden
Hasil koefesien determinasi Profitabilitas terhadap Kebijakan Deviden dapat dilihat hasilnya pada tabel berikut :

Tabel 8

Model Summary ${ }^{\text {b }}$

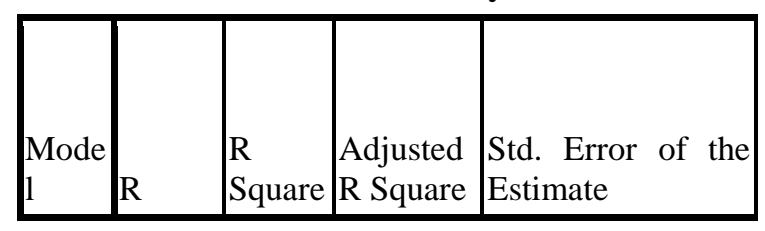

\begin{tabular}{|l|l|l|l|l|}
\hline 1 & $.212^{\mathrm{a}}$ & .045 & .036 & .25338400 \\
\hline
\end{tabular}

a. Predictors: (Constant), Profitabilitas

b. Dependent Variable: Kebijakan Devident

Berdasarkan tabel 4.8 tampilan output SPSS model summary, besarmya Nilai Adjusted $R$ Square adalah 0,036. Hal ini menunjukkan bahwa profitabilitas mampu mempengaruhi kebijakan utang sebesar 3,6\% sedangkan sisanya dijelaskan oleh faktor faktor lain yang tidak diteliti dalam penelitian ini.

\section{Analisis Jalur (Path Analysis)}

Untuk menguji pengaruh variabel intervening digunakan metode analisis jalur (Path Analysis). Analisis jalur merupakan perluasan dari analisis regresi. Analisis jalur menggunakan analisis regresi untuk menaksir hubungan kausalitas antar variabel (model causal) yang telah ditetapkan sebelumnya berdasarkan teori. Analisis jalur sendiri tidak dapat menentukan hubungan sebab-akibat dan juga tidak dapat digunakan sebagai substitusi bagi peneliti untuk melihat hubungan kausalitas antar variabel. Hubungan kausalitas antar variabel telah dibentuk dengan model berdasarkan landasan teoritis(Khuzaini,2009).

Untuk menghitung pengaruh langsung, digunakan formula sebagai berikut:

1. PengaruhProfitabilitas(X)terhadap Kebijakan Utang (Y):PengaruhX $\rightarrow$ Y $=-0.208$

2. Pengaruh Kebijakan Deviden (Z) terhadap Kebijakan Utang $(\mathrm{Y})$ : Pengaruh $\mathrm{Z} \rightarrow \mathrm{Y}=$ 0.106

3. Pengaruh Profitabilitas (X) terhadap Kebijakan Deviden (Z) : Pengaruh $\mathrm{X} \rightarrow \mathrm{Z}$ $=-0.212$

Sedangkan untuk menghitung pengaruh tidak langsung, digunakan formula sebagai berikut:

4. PengaruhProfitabilitas(X)terhadapKebijaka n Utang (Y) melalui Kebijakan Deviden (Z) $: \mathrm{X} \rightarrow \mathrm{Z} \rightarrow \mathrm{Y}=-0.212 \times(-0.208)=0.044$

5. Selanjutnya ditentukan pengaruh total dengan mengikuti formula sebagaiberikut: $\mathrm{X} \rightarrow \mathrm{Z} \rightarrow \mathrm{Y}=(-0.212)+(-0.208)=-0,420$

\section{Pembahasan \\ Hubungan Profitabilitas terhadap kebijakan hutang}

Berdasarkan output SPSS, hasil penelitian menunjukkan bahwa profitabilitas berpengaruh signifikan dan negatif terhadap kebijakan utang pada perusahaan manufaktur yang terdaftar di Bursa Efek Indonesia. Profitabilitas merefleksikan pendapatan untuk pendanaan investasi. menyarankan manajer untuk menggunakan pecking order untuk keputusan pendanaan. Pecking Order merupakan 
urutan penggunaan dana untuk investasi yaitu laba ditahan sebagai pilihan pertama, kemudian diikuti oleh hutang dan ekuitas. Jika ini benar, implikasinya adalah ada hubungan negatif antara profitabilitas perusahaan dengan debt ratio. Pihak insider tidak mau berbagi keuntungan dengan kreditur sehingga ada kecenderungan debt ratio perusahaan lebih kecil. Hasil penelitian ini sejalan dengan penelitian yang dilakukan Nurbaiti (2007) menemukan adanya pengaruh negatif dan signifikan antara profitabilitas terhadap kebijakan hutang. Hasil ini juga senada dengan penelitian yang dilakukan oleh Ismayanti dan Hanafi (2003). Pada tingkat profitabilitas rendah, perusahaan menggunakan hutang untuk membiayai operasional. Sebaliknya pada tingkat profitabilitas tinggi perusahaan mengurangi penggunaan hutang.

Hal ini disebabkan perusahaan mengalokasikan sebagian besar keuntungan pada laba ditahan sehingga mengandalkan sumber internal dan menggunakan hutang rendah tetapi pada saat menghadapi profitabilitas rendah perusahaan menggunakan hutang tinggi sebagai mekanisme pentransfer kekayaan kreditur kepada principal. Berbeda dengan hasil penelitian tersebut, Masdupi (2005) menemukan hasil yang tidak signifikan secara statistik antara profitabilitas terhadap kebijakan hutang.

\section{Hubungan kebijakan deviden terhadap kebijakan hutang}

Berdasarkan output SPSS, hasil penelitian menunjukkan bahwa kebijakan deviden berpengaruh positif namun tidak signifikan terhadap kebijakan utang pada perusahaan manufaktur yang terdaftar di Bursa Efek Indonesia.

Hasil

penelitian

yangtidaksignifikaninididugadisebabkanolehadanya

beberapa perusahaan di Indonesia menetapkan Kebijakan Dividen yang relatifstabilsetiaptahunnyauntukmenarikminatinvesto ragar menginvestasikandananya diperusahaantersebut,meskiutang perusahaan semakin bertambah maupun berkurang.Hal ini terjadi pada PTKimia Farma Tbk, PTLionMetalWorksTbk, PT SekarLautTbk, PTMandomIndonesiaTbk,PTTriasSentosaTbk, danP TTempo Scan PasificTbk.

Hasil Penelitian ini sejalan dengan penelitian yang dilakukan Dyah Ayu Clarashinta (2014) yang menemukan pengaruh positif namun tidak signifikan antara kebijakan deviden terhadap kebijakan utang dan Hasil Penelitian Firdayanti (2017) Kebijakan deviden tidak berpengaruh signifkan terhadap kebijakan hutang dimungkinkan karena adanya faktor lain yang mempengaruhi. Misalnya, perusahaan menerapkan kebijakan atas pembagian dividen stabil dimana perusahaan tetap membayar dividen meskipun laba yang diperoleh perusahan menurun atau perusahan mempunyai hutang. Dalam perspektif agency teory, ternyata meningkatkan pembagian dividen tidak dapat mengurangibiaya keagenan hutang dalam pengawasan masalah agensi, namun hubungan tersebut tidak berjalan secara efektif, sehingga kebijakan dividen tidak berpengaruh terhadap kebijakan hutang. Hal ini dikarenakan kemungkinan manajer tetap mengunakan hutang yang besar walaupun disatu sisi mereka membagikan deviden yang cukup besar.

Penelitan ini tidak berhasil mendukung pernyataan Taswan (2005), bahwa perusahaan yang mempunyai dividend payout ratio yang tinggi lebih menyukai pendanaan dengan mengunakan modal sendiri, sehingga dapat mengurangi biaya keagenan hutang. Disamping itu pembayaran dividen dapat dilakukan apabila semua kewajiban terhadap cicilan hutang beserta bunganya terpenuhi. Dengan demikian, akan membuat manajer sangat berhati-hati dalam mengunakan hutang.

\section{Hubungan profitabilitas terhadap kebijakan deviden}

Berdasarkan output SPSS, hasil penelitian menunjukkan bahwa profitabilitas berpengaruh negatif dan signifikan terhadap kebijakan dividen pada perusahaan manufaktur pada Bursa Efek Indonesia. Dengan demikian hal ini membuktikan bahwa kemampuan perusahaan dalam memperoleh laba mempengaruhi besarnya dividen yang dibagikan kepada pemegang saham. Bird inthe Hand Theory yang menjelaskan bahwa investor lebih menyukai pembagiandividen yang tinggi dibandingkan dengan dividen yang tidak dibagikan. Hal ini timbul dari pandangan investor yang paling pertama selalu menyatakan bahwa nilai perusahaan (harga saham) akan meningkat seiring dengan peningkatan dividen yang diberikan karena pembagian dividen yang dapat meningkatkan nilai perusahaan akan mengakibatkan peningkatan profit (capital gain) perusahaan sehingga perusahaan memiliki kemampuan untuk menghasilkan laba pada saat menjalankan kegiatan usahanya.

Hasil ini sesuai dengan penelitian yang dilakukan oleh Arilaha (2009) yang menyatakan bahwa besar kecilnya laba perusahaan akan mempengaruhi besar kecilnya pembagian dividen. Apabila laba perusahaan besar berarti dividen yang dibagikan akan semakin besar pula, demikian pula sebaliknya. Perusahaan yang memiliki stabilitas keuntungan dapat menetapkan tingkat pembayaran dividen dengan yakin dan mensinyalkan kualitas atas keuntungan mereka. Pembayaran dividen dapat menunjukkan sinyal bahwa perusahaan memiliki prospek yang baik.

Jika perusahaan mengumumkan peningkatan dividen, maka investor akan menganggap kondisi perusahaan saat ini dan akan datang relatif baik dan sebaliknya. Pada sisi lain penambahan dividen memperkuat posisi perusahaan untuk mencari tambahan dana dari pasar modal sehingga kinerja perusahaan dimonitor oleh tim pengawas pasar modal. Pengawasan ini menyebabkan manajer berusaha mempertahankan 
kualitas kinerja dan tindakan ini menurunkan konflik keagenan.

Dengan demikian profitabilitas mutlak diperlukan untuk perusahaan apabila hendak membayarkan dividen. Profitabilitas menggambarkan kemampuan perusahaan mendapatkan laba melalui semua kemampuan dan sumber yang ada. Ukuran profitabilitas dapat berbagai macam seperti: laba operasi, laba bersih, tingkat pengembalian investasi/aktiva, dan tingkat pengembalian ekuitas pemilik.

\section{PENUTUP}

\section{Kesimpulan}

Berdasarkanhasilanalisisdata

mengenaipengaruhprofitabilitas terhadap kebijakan utang melalui kebijakan deviden studi pada perusahaan manufaktur yang terdaftar di Bursa Efek Indonesia tahun 2015-2017 ,dapat disimpulkan bahwa:

1. Profitabilitas berpengaruh signifikan dan negatif terhadap Kebijakan Utang, hal ini dibuktikan dengan koefisien regresi kompensasi (b1) bernilai negatif sebesar 0,208 dengan signifikansi sebesar 0,026.Nilai signifikansi Profitabilitas $(0,026)$ yang lebih kecil dari nilai signifikansi yang diharapkan $(0,05)$ menunjukkan bahwa hipotesis pertama diterima, sehingga Profitabilitas dapat digunakan untuk memprediksi kebijakan utang perusahaan manufaktur yang terdaftar di Bursa Efek Indonesia tahun 2015-2017.

2. Kebijakan dividen tidak berpengaruh secara signifikan terhadap kebijakanutang ,hal ini dibuktikan dengan koefisien regresi kompensasi (b1) bernilai positif 0,106 dengan signifikansi sebesar 0,261. Nilai signifikansi kebijakan dividen $(0,261)$ yang lebih besar dari nilai signifikansi yang diharapkan $(0,05)$ menunjukkan bahwa hipotesis kedua ditolak, sehingga kebijakan dividen tidak dapat digunakan untuk memprediksi kebijakan utang pada perusahaan manufaktur yang terdaftar di Bursa Efek Indonesia tahun 2015-2017.

3. Profitabilitas berpengaruh negatif dan signifikan terhadap Kebijakan Deviden, hal ini dibuktikan dengan koefisien regresi kompensasi (b1) bernilai negatif $-0,212$ dengan signifikansi sebesar 0,023. Nilai signifikansi Profitabilitas $(0,023)$ yang lebih kecil dari nilai signifikansi yang diharapkan $(0,05)$ menunjukkan bahwa hipotesis ketiga diterima, sehingga Profitabilitas dapat digunakan untuk memprediksi kebijakan deviden perusahaan manufaktur yang terdaftar di Bursa Efek Indonesia tahun 2015-2017.

\section{Saran}

Berdasarkan hasil pengujian dan analisis pembahasan serta beberapa kesimpulan yang sudah dikemukakan pada penelitian ini, diharapkan dapat memberi gambaran mengenai Pengaruh Profitabilitas terhadap Kebiijakan Utang melalui Kebijakan Deviden Studi pada Perusahaan Manufaktur yang terdaftar di Bursa Efek Indonesia tahun 2015-2017. Tetapi penelitian ini masih memiliki keterbatasan-keterbatasan. Diharapkan penelitian ini dapat memberikan gambaran untuk penelitian selanjutnya agar dapat lebih baik. Adapun saran-saran yang dapat diberikan melalui penelitian ini sehingga dapat memberikan hasil yang lebih baik bagi penelitian selanjutnya, adalah sebagai berikut :

1. Peneliti menggunakan sampel perusahaan hanya pada perusahaan manufaktur, untuk itu disarankan bagi penelitian selanjutnya dapat menambah lebih banyak sampel yaitu dari beberapa sektor perusahaan sehingga dapat digunakan sebagai dasar generalisasi.

2. Penelitian ini membatasi pengamatan selama tiga tahun yaitu pada tahun 2015 sampai dengan 2017, disarankan untuk penelitian selanjutnya dapat melakukan penelitian untuk tahun-tahun berikutnya.

Untuk penelitian-penelitian selanjutnya diharapkan menambahkan variabel penelitian, sehingga dapat diketahui berapa besar pengaruh variabel independen dan variable intervening terhadap kebijakan hutang.

\section{DAFTAR PUSTAKA}

Firdayanti, 2017. Pengaruh Likuiditas Dan Profitabilitas TerhadapKebijakan Hutang Melalui Kebijakan Dividen(Studi Kasus Pada Perusahaan Non Keuangan Di Indeks Lq 45 Periode 2010-2015). Skripsi Jurusan Manajemen pada Fakultas Ekonomi Dan Bisnis UIN Alauddin Makassar. Pembimbing I : Dr. H. Abdul wahab,SE., M.Si., Pembimbing II : Rika Dwi Ayu Parmitasari, SE, M.Comm.

Sari Yulia Permata,2017. Analisis Pengaruh Profiabilitas, Likuiditas, Hutang dan Free Cash Flow Terhadap Kebijakan Deviden Pada Sektor Industri Barang Konsumsi Yang Terdaftar Di Bursa Efek Indonesia Periode 2013-2016. Tesis Program Pasca Sarjana Magister Manajemen Fakultas Ekonomi dan Bisnis Universitas Lampung Bandar Lampung. Pembimbing I : Dr. Sri Hasnawati, S.E., M.Si. Pembimbing II : Dr. Ernie Hendrawaty, S.E., M.Si.

Thaib Chaidir, Rita Taroreh, 2015. Pengaruh Kebijakan Hutang Dan Profitabilitas Terhadap Kebijakan Dividen (Studi Pada Perusahaan Foods And Beverages Yang Terdaftar Di Bei Tahun 2010-2014) Jurusan Manajemen Fakutas Ekonomi dan Bisnis Universitas Sam Ratulangi Manado.

Parmitasari Rika Dwi Ayu, Sutrisna, 2015. Pengaruh Profitabilitas Terhadap Kebijakan Dividen Tunai Dengan Likuiditas Sebagai Variabel Moderasi (Studi Terhadap 
Perusahaan Consumer Goods Yang Terdaftar Di Bursa Efek Indonesia Periode 2010-2014). Fakultas Ekonomi dan Bisnis Islam Universitas Islam Negeri Alaudin Makassar.

Pratiwi Ni Putu Diah, Made Mertha, 2016. Pengaruh Kebijakan Hutang Dan Profitabilitas Pada Nilai Perusahaan Dengan Kebijakan Dividen Sebagai Variabel Pemoderasi. Fakultas Ekonomi dan Bisnis Universitas Udayana Bali.

Nurillah Sofi, 2018. Pengaruh Struktur Kepemilikan Dan Profitabilitas Terhadap Kebijakan Hutang Dengan Kebijakan Deviden Sebagai Variabel Moderasi (Studi Pada Perusahaan Sektor Properti, Real Estate Dan Konstruksi Bangunan Yang Terdaftar Di Bursa Efek Indonesia Periode 2014-2016. Skripsi Jurusan Manajemen Fakultas Ekonomi Universitas Islam Negeri Maulana Malik Ibrahim Malang. Pembimbing : Muhammad Sulhan, S.E., MM.

Amaliah Nurul, 2016. Pengaruh Profitabilitas, Kebijakan Hutang Dan Dividen Terhadap Nilai Perusahaan Manufaktur Yang Terdaftar Di Bursa Efek Indonesia Periode 2011 - 2014. Fakultas Ekonomi dan Bisnis Islam Universitas Islam Negeri Alaudin Makassar.

Fatia Utami Vivi, 2017. Pengaruh Kebijakan Deviden, Profitabilitas, Leverage Dan Size Terhadap Nilai Perusahaan. Skripsi Jurusan Akuntansi Fakultas Ekonomi dan Bisnis Universitas Islam Negeri Syarif Hidayatullah Jakarta. Pembimbing : Yulianti S.E., M.Si.

Jilita, 2013. Pengaruh Kebijakan Deviden, Investasi Dan Profitabilitas Terhadap Kebijakan Hutang Pada Perusahaan Otomotif Yang Terdapat Di Bursa Efek Indonesia.

Latiefasari Hani Diana, 2011. Analisis FaktorFaktor Yang Mempengaruhi Kebijakan Deviden (Studi Empiris Pada Perusahaan Manufaktur Yang Terdaftar Di Bei Periode 2005-2009). Skripsi Program Sarjana Fakultas Ekonomi Universitas Diponegoro. Pembimbing : Dr. H.M. Chabachib M.Si.Akt.

Mayogi, Dien Gusti, 2016. Pengaruh Profitabilitas, Kebijakan Dividen Dan Kebijakan Utang Terhadap Nilai Perusahaan. Sekolah Tinggi Ilmu Ekonomi Indonesia (STIESIA) Surabaya

Maharani Puspa Devi, Dkk. 2017.Pengaruh Profitabilitas Terhadap Kebijakan Utang Melalui Kebijakan Deviden (Studi Pada PerusahaanManufaktur Yang Terdaftar Di Bei Tahun 2012-2014). Universitas Negeri Malang.

Nofrita Ria. 2013. Pengaruh Profitabilitas terhadap Nilai Perusahaan dengan Kebijakan
Deviden sebagai Variabel Intervening (Studi Empiris pada Perusahaan Manufaktur yang Terdaftar di BEI). Fakultas Ekonomi Universitas Negeri Padang.

Putra Bintang Asmanda, 2009. Pengaruh Kualitas Audit Terhadap Nilai Perusahaan Dengan Manajemen Laba Sebagai Variabel Intervening Di Industri Perbankan Indonesia. Skripsi Ekonomi Jurusan Akuntansi Fakultas Ekonomi Universitas Sebelas Maret Surakarta. Pembimbing : Dr. Hj. Rahmawati, M.Si, Ak.

Sunarya, Hoei Devi, 2013. Pengaruh Kebijakan Utang, Profitabilitas Dan Likuiditas Terhadap Kebijakan Dividen Dengan Size Sebagai Variabel Moderasi Pada Sektor Manufaktur Periode 2008-2011. Fakultas Bisnis dan Ekonomika.

Sumanti Jorenza, Marjam Mangantar, 2013. Analisis Kepemilikan Manajerial, Kebijakan Hutang Dan Profitabilitas Terhadap Kebijakan Dividen Dan Nilai Perusahaan Pada Perusahaan Manufaktur Yang Terdaftar Di Bei. Fakultas Ekonomi dan Bisnis, Jurusan Manajemen, Universitas Sam Ratulangi Manado.

Lestari Kekeu Firda, Tanuatmodjo Heraeni, Mayasari, 2016. Pengaruh Likuiditas dan Profitabilitas terhadap Kebijakan Deviden. Fakultas Ekonomi dan Bisnis, Jurusan Manajemen, Universitas Pendidikan Indonesia.

Clarashinta Dyah Ayu, 2014. Pengaruh Kepemilikan Manajerial, Kebijakan Deviden dan Profitabilitas terhadap Kebijakan Utang. Fakultas Ekonomi, Jurusan Manajemen, Universitas Negeri Yogyakarta.

Irwan Nur Mohammad, 2018. Pengaruh Kebijakan Hutang, Kebijakan Dividen, Profitabilitas Dan Kebijakan Investasi Terhadap Nilai Perusahaan (Studi Kasus Perusahaan Manufaktur Yang Terdaftar Di Indeks Saham Syariah Indonesia Periode 20142016). Fakultas Ekonomi dan Bisnis Islam, Jurusan Akuntansi Syariah, Institut Agama Islam Negeri Surakarta. 
